\title{
ON GIANTS IN SWEDISH ARCHAEOLOGY
}

Påvel Nicklasson

\begin{abstract}
Before the development of archaeology there were speculations that prehistory had been populated by giants. Giants are often seen in opposition to a scientific worldview and basic archaeological concepts. It has been emphasised that during the early i 9 th century there was a break between old beliefs and scientific archaeology. The author wants to show that the belief in giants in prehistory was essentially already gone. It was revived around $\mathrm{I} 800$ by an intensified interest in prehistory. It was central in formulating basic archaeological notions, such as the existence of a Stone Age. The belief in giants and the historicity of folk tales were part of romantic philosophy. The romantic roots of archaeology have been denied but are central for archaeological thinking.
\end{abstract}

Keywords: giants, Stone Age, early archaeology, history of archaeology, Nils Henrik Sjöborg, Magnus Bruzelius, Sven Nilsson, Johan Haquin Wallman, romantic philosophy

\section{INTRODUCTION}

An interesting paper by Mats Burström published after a TAG session called Archaeology and Folklore (Burström r999) serves as my point of departure for this essay on giants in early Swedish archaeology, which eventually ends with a discussion of the essence of archaeology. Burström argues in his paper that there was a division between scientific archaeology and an older antiquarian way to approach the ancient past during the igth century. The new discipline of archaeology focused on typology, chronology, and the measurement and division of time. This new discipline confronted old ways of looking on ancient 
monuments. Archaeology brushed aside antiquated notions of a prehistory populated by giants. "Most kinds of ancient monuments were associated with ancient giants. [...] [Giants] were supposed to have been the first inhabitants of the land" (Burström I 999:36). The disappearance of the giants implied that ancient monuments were instead explained by professional archaeologists in a historical framework. People living close to monuments, who had placed them in meaningful but atemporal contexts, had now very little to contribute. Modern archaeology was thereby separated from giants. When studying how archaeology was created during the early igth century it is therefore somewhat surprising to find that giants indeed retained a prominent role. This may call for a redrawing of the line between archaeology and science on the one hand, and giants and antiquarianism on the other. The first part of the essay explores some findings on giants. The second part demonstrates the importance of romantic science and philosophy for archaeological thinking.

\section{A SHORT HISTORY OF ARCHAEOLOGY}

Mats Burström's account is basically a traditional account of the history of archaeology. He adds to it a kind of Foucauldian approach, which emphasizes power and structures over personal initiatives in the history of science. During the I 9 th century scientific archaeology brushed aside old ways of looking upon the past. There was a sharp and distinct break between an old traditional way and a new scientific one. Burström states that the break occurred during the 1870 s (Burström 1999:37f). Burström sees the use of large-scale chronological schemes and the typological method as the most important parts of the new archaeological science. The development was led by Oscar Montelius and Hans Hildebrand. Burström agrees with most scholars who have studied the history of archaeology that this was a development of ideas launched in the I830s by the Swede Sven Nilsson and the Dane Christian Jürgensen Thomsen. Nilsson and Thomsen are seen as geniuses and founding fathers of archaeology.

Since I am more familiar with the Swedish source material than the Danish, I will focus on the development in Sweden. There is a wealth of papers and books on Sven Nilsson (Weibull 1923; Stjernquist I983; Magnusson Staaf 1994; Hegardt 1996, r997, to mention a few). It is noteworthy that, despite all that has been written about Sven Nilsson, there is still no scientific biography of him and his sources of inspiration. 
Lesser roles in the development of archaeology were played by Nils Henrik Sjöborg and Magnus Bruzelius, whose works preceded the breakthrough staged by Nilsson and Thomsen during the r. 830 . These scholars invented the concept of the Stone Age and speculated around the Three Age System. The concept of a most ancient Stone Age based on archaeological source materials was a necessary step for the Three Age System. Another important and somewhat later scholar was Bror Emil Hildebrand, who introduced the Three Age System in Stockholm. $\mathrm{He}$ there became Director-general of the Central Board of National Antiquities, and overcame the last remains of traditional opposition to the new ideas.

In the archaeological breakthrough during the early Igth century, the Stone Age, the Three Age System, and the use of a cultural anthropological approach to archaeology were introduced. These approaches laid the foundations for the later focus on systematic chronology, which is the focus of Mats Burström. In almost all accounts of the history of archaeology, the Three Age System and the development of an anthropologically related systematic chronology are considered to be the most important concepts for the scientific turn that archaeology took in the late I9th century (Weibull I923; Hildebrand I937a, I937b; Gräslund 1974, 1987; Trigger 1.989; Baudou 2004). According to this view of the history of archaeology, the turn of events was due to the geniality of a few scholars who broke with the traditional and scientifically unsound views of their contemporaries. The Foucauldian approach used by Mats Burström and other scholars such as Asgeir Svestad deviate from this view by emphasising structures over individuals (Svestad 1995; Burström I999). Nonetheless, the same events and scholars are still central. The inventions of the founding fathers are still regarded as scientific progress regardless whether they are seen as the results of discourses or of individual ingenuity.

This historiography of archaeology was established during the period I 920-I 940 by some very prominent and influential Swedish scholars, most notably Lauritz Weibull, Bengt Hildebrand and Henrik Schück (Weibull I923; Hildebrand r937a-b; Schück 1943). They worked during a period that has been called a Golden Age for the humanities in Sweden (Nordin 2008). This can broadly be characterised by a strong optimism in the power of science and a sense of the value of civilization and cultural heritage. It was natural that scholars looked for pioneers who seemed to have worked along similar lines and who established 
a framework for scientific thinking. The construction of the Stone Age and the Three Age System were seen as important breakthroughs towards scientific archaeology. On the negative side, scholars who did not contribute to the construction of these inventions were seen as traditionalists and unscientific. They were seen as romantic dilettantes with unscientific views on the past. It is emphasised that scientific archaeology broke with romanticism and a romantic interest in prehistory. Romanticism and the romantic episteme are held in low esteem by modern science.

It is fairly easy to reconstruct how it is assumed that modern archaeology distinguished itself from its pre-modern predecessors in this framework. It was born in the development of a new discourse. This led first to the realization of the existence of a Stone Age around I 820 by Magnus Bruzelius. The concept of a Stone Age was necessary for further progress, which led to the construction of the Three Age System. The system was presented by Thomsen $(1836)$ and was further elaborated by Sven Nilsson (Nilsson I $838-1843$ ). Their books have become classics of archaeology. In the process, traditional and unscientific antiquarianism was uprooted. Modern, or scientific, archaeology turned its back on folklore and traditional beliefs, including the belief in giants. Instead the focus was put on chronology. Scholars who have studied this process emphasise the scientific methods and sound scientific assumptions of key scholars such as Thomsen and Nilsson. "No doubt the traditional idea of a Three Age System was a fairly logical one, with some sound and reasonable thinking behind it. [...] Its success and its immense influence on archaeology can be attributed to the fact that it was worked out on sound scholarly principles" (Gräslund I98 I:45, 50).

Pre-modern archaeology, or antiquarianism, is seen as the opposite of modern or scientific archaeology. According to Burström (I999), it worked with an atemporal approach to prehistory. Its goal was to give meaningful explanations to complex (by scientific archaeology considered as chronologically multi-layered) landscapes, dotted with (for scientific archaeology) confusing and contradictory histories of ancient monuments. It was this landscape that surrounded ordinary people in the basically agrarian economy of the traditional world. Legends and myths were of prime importance. Pre-modern archaeology held traditional views on ancient monuments and the entities responsible for erecting them, based on legends and fairy tales. Traditional antiquarians 
believed in giants and other metaphysical and unscientific creatures.

As previously stated, this view on the history of archaeology was mainly created in the period 1920-I940, but several recent studies take a similar stance (e.g. Gräslund I974, I98 I; Hegardt I996, I997; Baudou 2004). In these presentations science is basically seen as progress. Positivism and empiricism are emphasised as basic components for archaeological thinking, even though especially Hegardt is sceptical to the "modern project". This does not mean that early antiquarianism is totally depreciated in all the studies. However, it is not seen as part of the archaeological "tradition" and is lacking in scientific foundations. A hard-read study that tries to look at the transition to modern archaeology in a slightly different way is Michel Notelid's Det andra påseendet (Notelid 2000).

If one should criticise the common view of a sharp break between romanticism and antiquarianism on the one side and scientific archaeology on the other, it has more in common with how science was seen in the I9th century than in contemporary society. A parallel case is the history of medicine. In the discipline of medicine, the romantic approach has until recently been denied all value. Instead a history that emphasises basically the same view as the history of archaeology has been adopted. Scientific progress was made first when some scholars broke with the romantic ideas. First with empiricism and positivism is it possible to speak of a real medical science. The influence of romantic thinkers and scientists on the discipline of medicine has largely been denied, although in fact very important steps were taken in medicine by romantic scholars (Hansson 2008).

The principal scholars who established the history of archaeology, Weibull, Schück and Hildebrand, were an historian, literary historian and historian of ideas respectively. I believe that they, occasionally, had vague ideas on how to evaluate archaeological excavations, research and methods. The history of archaeology has thus not been written by archaeologists but by scholars from other disciplines.

Based on the above, I argue that the established view is in need of some revision. I will show that the notion of a Stone Age and the Three Age System are founded on beliefs that may not be totally scientific. The new approach was perhaps not based "on sound and reasonable thinking" or "sound scholarly principles" (Gräslund I98 I:45, 50). Instead, in this essay I will argue that it has been founded on speculative thought, on a romantic vision of world history and an acceptance of 
unlimited imagination. The belief in giants may thus in the end have been necessary for the establishment of modern archaeology. I shall pursue the argument that, because the belief in giants was abandoned by traditional antiquarianism, this tradition was unable to construct new concepts for the understanding of prehistory. And I will further demonstrate that there was a more advanced use of chronological thinking in traditional antiquarianism than is often recognised. Traditional views were not necessarily atemporal.

\section{GIANTS IN PREHISTORY: THE MODERN VIEW}

To believe that prehistory was inhabited by giants is alien for modern archaeologists. It can therefore easily be viewed as a pre-modern or unscientific notion. Ola W. Jensen has studied how ancient the belief in giants in prehistory is (Jensen I999, 2002). In early times it was common knowledge that many ancient monuments had been constructed by giants. The view was widespread during the I 6 th and I 7 th centuries. However, during the I 8 th century the belief in giants in prehistory diminished alongside the growth of a more realistic and sceptical approach to history and antiquity. Several historical treatises in Sweden were devoted to correcting the fantastic views of Olof Rudbeck (I630I 702) as presented in his famous Atlantica. Scholars favoured sceptical interpretations that contradicted Rudbeck. The geological age of the earth was now perceived as rather short and the age of Sweden became even shorter. Within this view Sweden could not have been the home of all (un)historical events proposed by Rudbeck, who saw Sweden as the centre of the world and the locus of Atlantis. The growing disbelief in giants in prehistory is to be seen in this context. The belief in giants diminished when fantastic stories and fairy tales were disregarded and deemed to hold no historical truth. Leading historians at the end of the I 8th century denied the presence of giants in antiquity:

"Förnuftet I wår tid uppehåller sig icke wid käringsagor och gissningar. Jättar, troll och widskepelser finna bland oss hwarken rum eller wördnad" " Reason does not concern itself with old wives' tales and speculations, Giants, trolls and superstitions have no place or credibility among us"). (Olof von Dalin, quoted in Bring I945:193)

The conceptions of prehistory became more realistic, and around the turn of the 19 th century the giants had almost disappeared from his- 
torical treatises. But they were brought back to life a few decades into the Igth century by the great expansion of antiquarian research culminating in the founding of modern archaeology by Thomsen, Nilsson and their contemporary colleagues. In my opinion, the revived belief in giants at this time is of pivotal importance for the understanding of the history of archaeology.

However, the new belief in giants was not unconditional. Lengthy discussions often resulted in doubts about how substantial giants in prehistory were. Despite such reservations, one can find serious and lengthy discussions on giants in the writings of several of the leading antiquarians of the time. I will give examples of this from the writings of Nils Henrik Sjöborg, Magnus Bruzelius and Sven Nilsson. It is as if they felt compelled to discuss giants in prehistory, even if they did not totally believe in them as real creatures. Giants became important as a means to introduce the new, modern views of prehistory that opened up during the early igth century.

There was variation on how giants were perceived and presented. Sometimes they were regarded as a particularly primitive tribe inhabiting Sweden before the arrival of better known tribes such as the Götar and Svear. This tribe of giants was sometimes known as Jotar or Jotnar. The Jotar, Jotnar or giants were either assimilated into later immigrating tribes, or driven off into the wilds, especially to the wilderness of the northern mountainous parts of Sweden. Their perceived offspring in the northern mountains were the Finns and the people known in earlier times as the Lapps, both of whom were described as degenerate giants. One must here take into account the strong and old position of linguistics. Historical facts could be constructed on superficial similarities between words in different languages. Jotar and Jotnar are similar to the Swedish word for giants, jättar.

The giants - Joter, Jotnar, Lapps or Finns - lived in a crude and primitive time before the real history of the Götar and Svear had begun. During the early i 9 th century the Lapps and Finns were regarded as primitive peoples compared to "real" Swedes. This led to the idea that the Lapps and Finns, in early prehistoric times, had known only the use of stone as raw material. They did not know agriculture or the use of metals. These innovations were introduced by the latecomers, the Götar and Svear. Thus the idea of a primitive Stone Age was created.

Another way of looking on ancient giants was to see gianthood as more or less symbolic. Prehistoric people could have been taller than 
modern man, without being real giants. This could have been due to healthier ways of living. Tall prehistoric tribes could have been called giants by neighbours, despite their being normal humans.

The belief in giants could thus vary but had several common themes. I will give a few examples from leading antiquarians to illustrate this. Nils Henrik Sjöborg (I767-1838) wrote profusely on Swedish prehistory. He did more to popularize archaeology than he did actual research. His books are confusing and he often contradicts himself. His information on ancient monuments is often faulty. His contemporaries saw him as a poor scholar. Despite this he is seen as one of the precursors to modern archaeology. It has even been suggested that he was close to constructing the Three Age System (Hildebrand I937a:I47f; Baudou 2004: IO3). Sjöborg wrote about giants in several of his books, but it is rather difficult to interpret his texts and ascertain whether or not he really believed in giants. In Inledning til Kännedom om Fäderneslandets Antiquiteter he states that:

"Utan at tro människor fordon hafwa hunnit til 6 alnars högd, kunne wi likwäl wara försäkrade, at de gamle wida öfwerträffat oss i styrka, ty den vinnes genom öfning, och kanhända de äfwen i allmänhet warit af en något högre wäxt, hwilken tillika med en mera stadgad hälsa torde kunna ärnås genom et lefnadssätt, som är Naturen närmare" (Without believing that peoples of old times reached 6 ells, we can be assured that the ancient people were far stronger than we, because strength is achieved through practice, and perhaps they even in general were a bit taller than we, a tallness which, just as better health, would be attained by living closer to Nature). (Sjöborg I.797:97f).

Sjöborg's thoughts on giants reflect his views on a most ancient and primitive period in human history. This should have been equivalent to the Stone Age, even if Sjöborg never uses the term. In the later book Försök till en Nomenklatur för Nordiska fornlemningar (Sjöborg I 8 I 5), he returns to the giant problem. Sjöborg proposes here that megaliths had been erected by a very ancient people called Joter. Sjöborg does not discuss explicitly whether the Joter were giants or not, but it is obvious that there is a connection since he is relating popular names of megaliths such as Jättegrafvar, Jättestugor and Trollhus (literal translation: Giant tombs, Giant cottages and Troll houses) (Sjöborg I 8I 5:I 43). 
Magnus Bruzelius ( $1786-$ I 855 ) was one of the most talented Swedish antiquarians. It was he who first constructed a Stone Age based on archaeological finds. Sadly enough he abandoned his antiquarian studies and became a priest. This was a common fate for poor scholars, who had to look for ways to support themselves. In I 8I9 Bruzelius excavated a passage grave, Åsahögen in Qvistofta outside Malmö. Sven Nilsson helped him to analyse the bones (Bruzelius I 822). They were clearly from ordinary humans and not from giants, and therefore Bruzelius refrained from stories of giants in prehistory in his publication. Nonetheless, he is dependent on giants. He sees megalithic tombs as traces of the people Jotnar, who lived primarily in Jutland. From Jutland they wandered to southern Sweden, and everywhere they went they built megaliths. Thus, through the language of Bruzelius the megaliths remained indirectly associated with giants.

In other works Bruzelius more openly stated that there had been giants in Sweden:

"Jotiska Tidehwarwet, som innefattar hela den tid Swerge warit bebodt af Jättar eller Jotar före Asarnas hitkomst" (The age of the Jotes, which comprises the entire time Sweden has been inhabited by giants or Jotar before the arrival of the Æsirs). (Bruzelius r8 8 I $7: 20)$

Bruzelius touches upon one of the main sources of knowledge of Sweden's ancient past: the Edda and other medieval Icelandic sagas. In these there are tales about the Æsirs, foremost Thor, battling against giants. The sagas were seen as true representations of historical relations, comparable to the accounts of Greek and Romans historians. One of the difficulties for Bruzelius and his contemporary colleagues was to compare the archaeological record with historical sources. Large megaliths came in handy. They became monuments after the giants mentioned in the saga literature. A strong belief in Icelandic sagas was shared by all antiquarians in the beginning of the I9th century and formed the general outlook on prehistory.

Sven Nilsson ( $1787-\mathrm{I} 883$ ) began his writings on prehistory rather late. For him, the question of giants was central. Nilsson gave great credibility to folk tales of giants, especially when they were combined with ancient monuments. He believed that the tales contained historical truths: 
"Det skulle väl kunna hända att detta ger mig mod att redigera och utgifva de talrika sägner om troll och jättar som är gängse bland allmogen och som synes mig hvila på rent historisk grund oaktadt allt det äfventyr och orimliga, hvarmed de äro uppblandade" (It could so happen that this gives me the courage to edit and publish the numerous tales about giants and trolls that are common among the country people and appear to me based on pure historical ground despite all the adventure and absurdities they are mixed with). (Sven Nilsson to Christoffer Gyllenstierna I835, quoted in Gustavsson 2003:67)

In his famous book Skandinaviska Nordens Ur-invånare (Nilsson I $838-1843$ ), a whole chapter, almost a fourth of the volume, is devoted to the giant question. Nilsson's conclusion is that there had not been real giants or dwarves in prehistory. Giants and dwarves were instead prehistoric tribes of ordinary humans of large or small stature. The small people called their large neighbours giants. The tall people called their small neighbours dwarves. Thus Nilsson found proof in folk tales that they mirrored prehistoric events:

"Vi hafva således visat att Dvergar och Jättar voro olika folkstammar i Skandinavien. [...] Att dessa hedniska, mer och mindre råa stammar förde blodiga krig med hvarandra, derpå lemna våra fornsagor och folksägner många tydliga bevis, hvilka dock ofta blifvit öfversedda eller missförstådda och förklarade för blotta dikter, allegorier och myther" (We have thus shown that dwarves and giants were different peoples in Scandinavia. That these heathen, more or less brutal tribes waged bloody wars with each other is proven by ancient sagas and folk tales with good evidence; they have, however, often been overlooked or misunderstood and explained as mere poems, allegories and myths). (Nilsson $1838-1843:$ I 63 )

Giants were thus central for all the antiquarians, Sjöborg, Bruzelius and Nilsson. All three are major figures in the history of archaeology. In the writings of Nilsson the giants are declared to have been ordinary peoples. From Nilsson and thereafter, giants were "undemonised" and integrated into archaeology. All the antiquarians expressed more or less doubt as to whether giants in prehistory were real. But the most important issue for the argument I want to make here is that they chose to 
discuss giants at length or to allude to connections between prehistoric peoples and ancient monuments and giants. The giants were needed to be able to grasp a prehistory vastly different from the antiquarians' own time period.

Sjöborg, Bruzelius and Nilsson all studied in Lund. This provided the empirical background for their antiquarian research. In Lund the collection of the Historical Museum was among the largest in Scandinavia. Stone Age artefacts vastly dominated, while objects from the Iron Age were rare. Megaliths and mounds, either concealing Stone Age constructions or Bronze Age tombs, dominated the antiquarian landscape in Scania. Cemeteries from the Iron Age had mostly been destroyed by tilling, or were relatively invisible. The basic constitution of the source material made it natural to speculate about an age inhabited by people who knew only the use of stone and who erected tombs or buildings of huge dimensions. They must have been a people vastly different from us modern men. Had they in fact been giants?

\section{GIANTS IN PREHISTORY: A TRADITIONAL VIEW}

The new views on prehistory broke with traditional views and formed the basis of modern archaeology. The traditional views are seldom analysed. It is even hard to find any traditional antiquarians in textbooks on the history of archaeology. The traditional antiquarianism is like a ghost. It represents all the bad and is the counterpart to what archaeology should be. Still, it is faceless.

I think I have found one candidate whose views on the Stone Age, giants and prehistory could be used as a counterpart to modern archaeology. It is the antiquarian Johan Haquin Wallman (I 792-I 853 ). Very little has been written on this pioneer and his extensive antiquarian activity. He was seen as one of the best antiquarians of his time. He won prestigious awards for essays and was mentioned with respect by colleagues. Still, when he is later mentioned in connection to the history of archaeology, he is often described as a hardened traditionalist, in opposition to the new scientific archaeology. His scientific achievements are seen as minimal and of no value (Hildebrand I937a:329f; r $937 \mathrm{~b}: 533 \mathrm{f}$; Schück I 943:I94f). Even in the most recent textbook on Swedish history of archaeology Evert Baudou relegates him to a footnote (Baudou 2004:388). In a dissertation within the history of ideas, Torkel Molin shows that Wallman in fact did important research and was a skilled antiquarian (Molin 2003). For my argument it is enough to conclude 
that there seems to be near consensus on Wallman as a representative for traditional antiquarianism. So, did he believe in giants?

Most definitely not! In several works he was sharply opposed to the crazy view of giants in prehistory. He pleaded that prehistory had been inhabited by normal humans and that all humans had common ancestry. One example is from his treatise Öfversigt af Svenska fornlemningar, med anvisning till deras kännedom och beskrifning (Wallman 1838 ). Here he says that the huge dimensions of some ancient monuments have led scholars to believe that they were built by giants. He refutes this by stating:

“Den förvåning, som dessa stenmassor hos åskådaren väcka, minskas likväl, när man blifvit bekant med den undransvärda styrka vid massors rubbning, som redan af enskilda ibland Svenska Allmogen utvecklas" (The awe these masses of stone awaken is diminished when one notices the admirable strength that certain country people demonstrate when they move great volumes). (Wallman I 838:7 If)

He then correctly states that no giant skeletons have been found in ancient monuments, only remains of ordinary humans. The oldest peoples were instead, according to Wallman, the Lapps and Finns; they were just as human as we, despite the fact that they were primitive.

Wallman's opposition to giants in prehistory is closely connected to opposition to the notion of a Stone Age, a time when humans did not know agriculture or the use of metal. His essays therefore contain indirect critique of antiquarians such as Sjöborg and Bruzelius. In Wallman's view humans originated in a Golden Age. Primitive people had forgotten the use of metal and agriculture. This was a commonly held view during the romantic era. It excluded, of course, the possibility of an original Stone Age, with or without giants.

The resulting picture is confusing. Scientific archaeology began with the realization of the existence of a Stone Age. The realization of the Stone Age was reached through belief in, or at least lengthy discussions of, giants that inhabited this utmost alien time. When reading the old antiquarians, it seems that they had to picture a world with imagined entities, such as giants, to be able to fathom this strange world that was so totally different from their own, even if they did not really believe in giants per se.

In contrast, most historians and antiquarians, who are often called traditionalists, had abandoned the belief in giants already in the $I 8$ th 
century. Wallman can be seen as a late representative of this sceptical tradition. He and others saw prehistory as inhabited by ordinary humans. By doing so, they unfortunately also abandoned the instruments to construct an alien world, such as the Stone Age. In Wallman's writings prehistory is basically the same agricultural society as the one he himself lived in.

Most of the so-called traditional antiquarians, including Wallman, had studied in Uppsala. Around Uppsala, as well as in most regions of middle Sweden, Stone Age monuments and artefacts are rare. The landscape is dominated by Iron Age cemeteries. Most antiquarians thus worked with documenting and excavating Iron Age graves and cemeteries. The saga literature provided most of the historical background needed to give interpretations of the monuments. The Stone Age, and the associated giants, was a non-question. Wallman is one of the few who address the question at all. Even after Bror Emil Hildebrand introduced the Three Age System in Stockholm in the I 83 os, the Stone Age and the new chronological system were often ignored. This was not due to fossilized thinking or stupidity. Rather, it was due to the limited use of these new lines of thinking in the middle parts of Sweden.

Seen from this perspective, the division is not so much between traditional and modern archaeology as it is between students from Lund University and Uppsala University. Antiquarians from Lund are seen as proponents for modern archaeology. Their work is part of the history of archaeology. Students from Uppsala are seen as traditionalists and have been more or less forgotten. Uppsala was by far the largest and most important university in Sweden, yet the developments in archaeology in Uppsala during the early Igth century have only to a limited degree been studied. A big portion of the Swedish history of archaeology thus remains unexplored.

\section{CHRONOLOGY}

The Stone Age was a prerequisite for the Three Age System. The Three Age System has been seen as the foundation of prehistoric chronology and a modern approach to prehistory. This is the foundation of modern archaeology. This approach was impossible to take for traditionalists, who viewed prehistory as atemporal.

It is very easy for us to look on the Three Age System as an evolutionary schedule on human development. This is not how the creators looked on it, since it was constructed before Darwinism. The creators 
held views that differ greatly from how we today look on chronology, time and change. It is in fact hard to imagine how people looked upon these things before our own time, when notions such as evolution and progress decide how we view time and prehistory. In Thomsen's famous Ledetraad, where he outlines the Three Age System, there are very few clues as to how Thomsen looked on chronology and change. It should be fairly obvious that the Three Ages represented different times and peoples. How change occurred over time is, however, more unclear.

Sven Nilsson is almost as obscure, even if he discusses the Three Ages in more detail. I have previously pointed out how Sven Nilsson was influenced by the French natural scientist Georges Cuvier (Nicklasson 2008, cf. Hegardt 1997:chap. 5). Cuvier saw prehistory as consisting of a number of stages. There was no development from one stage to another. Instead change occurred through catastrophes. God repeatedly destroyed his creation and recreated the world. I believe Sven Nilsson adopted this view from natural science and applied it to prehistory. Change occurred through violent migrations. Prehistoric peoples had repeatedly been exterminated by more advanced ones. There was no real development between phases.

Nowadays Cuvier is seen as an important figure in the history of natural sciences. His speculations on God's repeated destruction of the creation is seen as speculative natural philosophy. Nilsson's outlook was thus founded in the speculative thought of natural philosophy. Natural philosophy has nowadays been abandoned by science in favour of natural science. Natural philosophy is the non-scientific cousin found in New Age beliefs, alternative medicine, among green fundamentalists and other movements which we do not normally want to associate with scientific archaeology. But Sven Nilsson had no problem with this. It could thus be argued that the foundation of his research and his justification of the Three Age System is, in a strict sense, scientifically unsound.

Traditional antiquarians are said to have had no understanding of matters of chronology. Once again I call upon Johan Haquin Wallman to illustrate how advanced the traditionalists' thinking had become. During the late I 820 S Wallman elaborated on a prehistoric burial chronology. Just the fact that he worked on a chronological system could refute the notion of traditionalistic disinterest in chronology. Wallman's chronology was based on Sturluson's epic tales of changes to the burial rites connected with the immigration of Odin and the Svear 
during the Iron Age. Sturluson's tales are now regarded as a dubious source for scientific details and impossible to use to construct prehistoric chronologies. It is, however, important to understand Wallman's chronology as basically an Iron Age chronology, which is the same period that Sturluson writes about. Wallman expanded Sturluson's chronology by empirical observations and new methods. He denied the existence of a Stone Age, and had just a vague idea of an early Bronze Age preceding the times of the sagas. Wallman worked with the basic assumption that pottery in graves was present only in an early part of prehistory (Wallman I 838:74f, and in several letters and manuscripts). During later phases there was no pottery. Of course Wallman should have been wrong. Or was he indeed? I find it plausible that Wallman had observed the difference between burials from the Early Iron Age, often found in ceramic vessels (so-called urn burials), and cremation layers in Late Iron Age mounds. Wallman did not have modern words to describe what he had seen.

The important point here is not to argue whether Wallman was wrong or not, but to analyse the method he used. To study which objects there are in burials from a certain period and which objects are lacking, is a crude use of find combinations. Today this is the standard method used by archaeologists to establish chronologies. The forgotten traditionalist thus elaborated on quite advanced means to work with chronology.

\section{THE CREATION OF ARCHAEOLOGY}

As we have seen, it is doubtful that modern archaeology had stronger scientific foundations than traditionally held views. Fundamental notions such as the existence of a Stone Age were based partly on quite unscientific assumptions of the existence of giants in prehistory. Several studies on the history of archaeology state that the belief in giants was traditionalistic. It is not a part of modern archaeology. It is impossible to combine the belief in giants held by Sjöborg, Bruzelius and Nilsson with their foundational archaeological thoughts. To solve this paradox, the belief in giants is seldom mentioned. Instead, only the scientific parts of early archaeology are studied.

I believe it is not correct to see the belief in giants as something which is relevant only for the romantic and traditional. In his study on the history of archaeology Ola Jensen denotes all beliefs in giants as traditional. Mats Burström does the same in his TAG paper. As we have seen, 
the belief in giants in prehistory almost disappeared during the $\mathrm{x} 8 \mathrm{th}$ century. This development was nullified by the creators of archaeology, who reintroduced the giants. The giants were necessary for them to be able to construct modern views of archaeology and prehistory. I see their belief in giants as not being connected to traditional thinking, but as quite revolutionary and an important part of how archaeology was founded. The antiquarians of the early i 9 th century did not primarily use ancient and traditional sources to strengthen their arguments of the presence of giants in prehistory. Folk tales were used as important sources of information. The tales were, however, interpreted in a new framework. The antiquarians refer to the very latest research. The belief in giants linked them to contemporary romantic philosophy.

Giants were fundamental to understanding history during the romantic era. The greatest philosopher of the period was the German idealist Friedrich Schelling (I775-I854). As a gentleman and dilettante, Schelling was well versed in antiquarian research. Prehistory is central in his philosophical system of world history. Schelling saw man's beginning in a Golden Age. From this paradise man fell into history. Schelling's own time period, based on science, held little respect for nature. In his opinion, by means of idealistic thinking and correct actions it would be possible to regain paradise lost. One way to do this was to study prehistory. Schelling's system stated that the older an ancient monument or artefact is, the closer to the primordial paradise in which it had been created. It could give important clues on how to re-enter paradise. His philosophy accordingly led to an increased interest in exploring man's most ancient past. It was a true revolution. During the I 8 th century the most ancient times were seen as primitive, brutal and irrational. They were thus not worth studying. But according to Schelling, the study of the ancient past made it possible to gain glimpses of paradise lost and hints of how to regain it. Schelling also had thoughts about giants in prehistory. He stated that ancient man, who dwelled in the presence of God, was perfect. Ancient man held divine knowledge. He was intellectually far more advanced and greater than present-day humans. He was also physically superior - a giant compared to us later dwarves (Schelling I 860:58f, I907).

Schelling was extremely popular in Sweden and his philosophy was eagerly studied (Nordin 1987). If one reads Schelling's texts alongside those of Sjöborg, Bruzelius, Nilsson and Wallman, it is much easier to understand their arguments. It is obvious that they were influenced by 
him. The belief in giants was in no way traditional. Instead it shows that the leading antiquarians were aware of the latest theoretical texts. The changes in archaeology are linked to philosophical and theoretical questions on how to look on the world and the past. The influence from Schelling and the creation of archaeology should be further explored.

\section{SOME THOUGHTS ON THE ESSENCE OF ARCHAEOLOGY}

There was no difference between scientists and dilettantes in archaeological research during the I9th century. Dilettantism was in fact a prerequisite for archaeology. In a study of the history of German archaeology, Suzanne Marchand points out that it was dilettantism and amateurism that enabled early German archaeologists to think along new lines. These were different from traditional interpretations of history (Marchand I996:52f). Prehistoric study and early archaeology were not academic disciplines taught in universities. Prehistory was studied locally by amateurs. It had strong local and patriotic roots. The position outside the academies, and the flourishing amateurism, led to that traditional views held by professors at the universities were ignored. At the universities, the primary source of information on prehistory was written sources from ancient Greece and Rome. Thus, it was the ancient Mediterranean world that was studied. German prehistory was ignored or only studied indirectly. The field was mostly left to amateurs. The amateurs speculated wildly about the character of prehistory. This was done by a combination of unfamiliarity with established science, traditional views, folk tales and an almost unlimited imagination. One should also include the revolutionary ideas of philosophers such as Kant, Fichte and Schelling who changed the way we look on ourselves and on the world. Out of this mix, archaeology finally was created. The situation appears to have been similar in Sweden. Archaeology was not a discipline at the universities. All antiquarians were amateurs. The studies were conducted in a patriotic spirit. Studies and excavations were often carried out in a local context.

This indicates that archaeological thinking from the start was not based on logical, sound, academic thinking and scholarly principles. Instead, the crucial prerequisite for an antiquarian is the ability to imagine a world totally alien to his own and to combine knowledge from disparate fields. In this perspective it is easier to understand the role of giants in early archaeological research. Without them it would have been impossible for Sjöborg, Bruzelius and Nilsson to construct some- 
thing as alien as a Stone Age. A most ancient Stone Age was a break with some 2000 years of historical writing. The giants were necessary to be able to grasp the possibility of a world older than the Bible (thus before the creation), where ungodly brutes lived. The way to imagine such a world was through myths and mythical beings. The giants were a means to reach the end, to create a modern or scientific archaeology. This was a great achievement. When one reads articles, journals and letters from the early igth century, it is obvious how difficult it was to formulate such a radically new understanding of world history. ${ }^{1}$

The imagining of alien worlds must be combined with new theories on how the world is constituted. Imaginative thinking and the new theories together formed basic elements of the new science of archaeology. The theories included Schelling's world view, the Three Age System, and catastrophe theories along with Cuvierian natural philosophy. These were explored by antiquarians during the early igth century. These theories have in common that they claim to be universal. They claim to give coherent visions of how the world functions. To strengthen the argument, empirical material was used. This could be ancient monuments or artefacts. Imagined worlds thus became more believable, since their material traces could be observed and even touched. In a nutshell, and perhaps a little provocatively, this is how scientific archaeology was created. It is just as romantic a science as the traditional archaeology. Romantic science emphasised intuitive thinking and strokes of ingenuity. It is important to emphasise that empirical foundations to arguments were almost as important and made theories believable (Hanson

1 One example of how problematic the creation of the Stone Age was can be found in an anonymous review of Iduna IX from 1822 (Stockholmsposten 185 Monday 12 August 1822). In Iduna the antiquarians Bruzelius and Wallman had presented sharply conflicting views on the oldest history of man (Bruzelius 1822, Wallman 1822a-b). The reviewer agrees with the standpoint of Bruzelius and dismisses Wallman. Wallman comments sharply on the review in a letter to Jacob Adlerbeth, where he states that humans in prehistory lived simple lives but were not savages (LSB Br 5a Wallman to Adlerbeth 9 April 1823). Wallman could never accept that there could have been a primitive Stone Age.

Jacob Adlerbeth was the leading member of the famous Götiska förbundet and held a key position in Swedish antiquarian research. Magnus Bruzelius discussed his view on human origin with Adlerbeth as well. There is a collection of letters from Bruzelius to Adlerbeth which could be combined with information in the diary of Adlerbeth to reconstruct the process Bruzelius went through when he formulated the theory of the existence of a primitive Stone Age (ATA GFOJAA letters from Magnus Bruzelius to Jacob Adlerbeth, UUB 850b Jacob Adlerbeth's diary volume 2 1818-22). Another illustrative collection of letters is the correspondence from Sven Nilsson to Abraham Ahlquist, an antiquarian living on Öland (KsoGB letters from Sven Nilsson to Abraham Ahlquist). The letters give a summary of the career of Nilsson and information on how Nilsson began his research in archaeology and some of his views on prehistory. 
2008:220). Early archaeology has more roots in romantic philosophy and science than have so far been recognised.

Even today the ability to imagine a bygone alien world is a prime requisite for an archaeologist. This is done by saying that prehistory was in one way or another different from the world at hand. The imagined world is combined with theories such as typology, some postprocessual theory or other ideas with universal claims. The theories give the rules that govern the imagined world. Artefacts and ancient monuments are drawn into the study. This makes the imagined world and theories believable. They are proven by material remains. Without these romantic traits archaeology may not even be possible. If you are not able to imagine that people could live in a way totally different from your own, or a world that functions in a totally different way from the one you can observe around you, it is not possible to study archaeology. You would instead study the world as it is and what is observable. This is science. It is not archaeology.

In my reading of archaeology, it is close to how Schelling and other romantics looked upon science. In Schelling's thinking, science is a combination of speculative thinking and empirical study. Speculative thinking is based on assumptions that the world can be totally different than it appears to be. Speculations are combined with theories on how the world functions, such as Schelling's own historical vision. This was seen as God's hidden agenda unmasked by poet-philosophers such as Schelling himself. Empirical studies strengthen his arguments. The influence from Schelling and other romantics has largely been denied in the history of archaeology. I think that serious scholars do not want to be mixed up with poets or admit that they devote themselves to speculations.

What, then, was the difference between the early archaeologists and traditionalists such as Johan Haquin Wallman? Wallman's chronological thinking and use of archaeological artefacts to establish prehistoric chronologies were advanced. His system was based on common sense and scientific methods. He was a scholar who reflected on what was observable around him. It could be noted that science is often said to concern itself with observable facts. Wallman could therefore be seen as "too" scientific to pass as an archaeologist. He failed to imagine a prehistoric world decisively different from his own. The most primitive peoples he could imagine in prehistory, the Lapps and Finns, lived as nomads, just as their descendants in the I 9 th century. As a result 
his system lacked universal claims of, for instance, the Three Age system, and therefore it failed to convince. It could be claimed that the traditionalist Wallman was more critical and held a more sceptical and perhaps even more scientific attitude toward the past than some of his more celebrated contemporaries. And perhaps that is why he is not regarded as an important figure in the history of archaeology.

\section{CONCLUDING REMARKS}

It is time to return to Mats Burström's paper from TAG, which was my starting point for the essay. His paper concludes with a post-modern vision of archaeology. Ancient monuments should be studied by acknowledging the multiple meanings they have. Burström wants to revive a romantic life-world in relation to ancient monuments. The monuments should be reconnected to local and popular beliefs. According to Burström, the world and ancient monuments were once full of meaning. Meaning has been destroyed by too much science and modern thinking. Meaning is to be recreated by archaeologists engaging in dialogue with the general public. The post-modern struggle to re-enchant the world and recreate meaning for individuals goes back to romanticism in the early I 9 th century. Schelling is a major source of influence for post-modern icons such as Heidegger, Sartre and Derrida (Bowie 1993). Post-modern or post-processual archaeology is another vessel for romanticism. Burström does not mention any romantic roots for his view. Perhaps it is still too embarrassing to confess to be a romantic, uniting speculation and empirical study with tales of bygone and strange worlds, even for a post-modern archaeologist.

Påvel Nicklasson, Silvergården 7 B, 26 I 43 Landskrona, Sweden

\section{References}

Anon. 1822. Review of Iduna IX. Stockholmsposten I 85, Monday I 2 August I 822. Baudou, E. 2004. Den nordiska arkeologin - bistoria och tolkningar. Stockholm: Kungl. Vitterhets Historie och Antivititets Akademien.

Bowie, A. 1993. Schelling and Modern European Philosophy. An Introduction. London/New York: Routledge.

Bring, S. E. 1945 . Källor och litteraturförteckning. Sveriges historia till våra dagar. XV. Stockholm: Norstedts. 
Bruzelius, M. 1817. Swerges historia för ungdom. Hedniska tiden Första afdelningen. Lund.

Bruzelius, M. I822. Nordiska fornlemningar från Skåne. Iduna, Nionde häftet.

Burström, M. r999. Focusing on time: disciplining archaeology in Sweden. In: GazinSchwartz, A. \& Holtorf, C. (Eds.). Archaeology and Folklore. London: Routledge.

Gräslund, B. I 974. Relativ datering. Om kronologisk metod i nordisk arkeologi. TOR. Vol. XVI. Uppsala.

Gräslund, B. 198 I. The background to C. J. Thomsen's Three Age System. In: Daniel, G. (Ed.). Towards a History of Archaeology. London: Thames and Hudson.

Gräslund, B. 1987. The Birth of Prehistoric Chronology. Dating methods and dating systems in nineteenth-century Scandinavian archaeology. Cambridge: Cam bridge University Press.

Gustavsson, K. 2003 . "... min stora kärlek för allt, huad fornforskningen rörer" Carl Gyllenstierna, fornforskaren på Krapperup och hans tid. Nr i 8 i serien Krapperups museum. Nyhamnsläge: Gyllenstiernska Krapperupsstiftelsen.

Hansson, J. 2008. Den romantiska medicinen. In: Broberg, G. (Ed.). Til at stwdera läkedom Tio studier i svensk medicinhistoria. Lund: Sekel.

Hegardt, J. 1996. Sven Nilsson and the Invention of Modern Man. Current Swedish Archaeology. Vol. 4. Pp. 5 T-68.

Hegardt, J. 1997. Relativ betydelse Individualitet och totalitet $i$ arkeologisk kulturteori. OPIA. 12. Uppsala: Uppsala universitet.

Hildebrand, B. I937a. C. J. Thomsen och hans lärda förbindelser i Sverige $1816-$ 1837 Bidrag till den Nordiska forn-och häudaforskningens bistoria I Tiden till 1 826. Kungl. Vitterhets Historie och Antikvitets Akademiens Handlingar. Del 44:1. Uppsala.

Hildebrand, B. 1937b. C. J. Thomsen och hans lärda förbindelser i Sverige I8I61837 Bidrag till den Nordiska forn- och hävdaforskningens historia II Tiden 1826-1837. Kungl. Vitterhets Historie och Antikvitets Akademiens Handlingar. Del 44:2. Uppsala.

Jensen, O. W. 1999. Forntid i samtid Om Lennart Åbergs och Axel Emanuel Holmbergs forntidsuppfattningar. In: Gillberg, A. \& Gustafsson, A. (Eds.). Västsvenska arkeologihistorier. GOTARC Serie C. No 24. Gothenburg: Gothenburg Universiry.

Jensen, O. W. 2002. Forntid i bistorien: en arkeologibistorisk studie av synen pa forntid och forntida lämningar, frän medeltiden till och med förupplysningen. GOTARC Serie B Gothenburg Archaeological Theses. no 1.9. Gothenburg: Gothenburg University.

Magnusson Staaf, B. 1994. An Essay on the Theory of History in Stvedish Archaeology. Report series. No. 50 . Lund: Lund University.

Marchand, S. L. 1996. Down from Olympus Archaeology and Philhellenism in Germany, 1750-1970. Princeton: Princeton University Press.

Molin, T. 2003. Den rätta tidens mått Göthiska förbundet, fornforskningen och det antikvariska landskapet. Skrifter frän forskningsprogrammet Landskapet som arena. nr 6. Umeå: Umeå universitet.

Nicklasson, P. 2008. Johan Haquin Wallman, Sven Nilsson och den moderna arkeologins genombrott. Fornuännen $\mathrm{Vol}$ I03. Pp. IO2-1 10.

Nilsson, S. I8 8-1843. Skandinaviska nordens ur-invainare ett försök $i$ komparativa ethnografien och ett bidrag till menniskoslägtets utvecklingshistoria. Stockholm.

Nordin, S. 1987. Romantikens filosofi Suensk idealism frän Hoijer till hegelianerna. Lund: Doxa. 
Notelid, M. 2000. Det andra påseendet En studie au övergångar $i$ den arkeologiska disciplinens historia. OPIA 22. Uppsala: Uppsala University.

Nordin, S. 2008. Humaniora i Sverige Framväxt Guldalder Kris. Stockholm: Atlantis.

Schelling, F. W. J. т 860. Philosophic und Religion. Sämmtliche Werke 1804 . Sechter Band. Stuttgart und Augsburg: J. G. Gottascher Verlag.

Schelling, F. W. J. I 907 . Vorlesungen über die Methode des akademischen Studiums. I Weiss, O. (red.) Schellings Werke. Zweiter Band. Leipzig: Fritz Echart Verlag.

Schück, H. 1943. Kgl Vitterhets Historie och Antikuitets Akademien dess förhistoria och bistoria. VII Akademien 1 794-1826. Stockholm: Kungl. Vitterhets Historie och Antivititets Akademien.

Sjöborg, N. H. 1797. Inledning Til Kännedom af Fäderneslandets Antiquiteter: Lund.

Sjöborg, N. H. 1815. Försök till en Nomenklatur för Nordiska Fornlemningar. Stockholm.

Stjernquist, B. I983. Sven Nilsson som banbrytare i svensk arkeologi. In: Regnéll, G. (Ed.). Sven Nilsson En lärd i i 800-talets Lund. Lund: Kungl. Fysiografiska Sällskapet i Lund.

Svestad, A. 1995. Oldsakennes orden. Oslo: Universitetsforlaget.

Thomsen, C. J. 1 836. Ledetraad til Nordisk Oldkyndighed. Copenhagen: Det kongelige Nordiske Oldskrift-Selskab.

Trigger, B. G. I989. A History of Archaeological Thought. Cambridge: Cambridge University Press.

Wallman, J. H. ı 822a. Om striden på Samsö ett historiskt och geografiskt bidrag till Nordens fornkunskap, i anledning af Herwara sagan. Iduna, Vol IX.

Wallman I 822 b. Ett Indiskt skrifttecken ibland runorna. Iduna, Vol IX.

Wallman, J. H. I 838. Öfversigt af Svenska fornlemningar, med anvisning till deras kännedom och beskrifning. Kungl. Vitterhets Historie och Antikvitets Akademiens Handlingar. 14.

Weibull, L. 1923. Det arkeologiska treperiodsystemet. Dess uppkomst och giltighet. Historisk tidskrift för Skäneland. Femte Bandet.

\section{Archive sources}

LSB (Linköpings Stiftsbibliotek): Br 5 a Wallman to Adlerbeth 9 April r.823.

ATA GFOJAA (Antikvariska Topografiska Arkivet; Götiska Förbundets och Jacob Adlerbeths Arkiv, Stockholm): letters from Magnus Bruzelius to Jacob Adlerbeth.

UUB (Uppsala Universitetsbibliotek): $850 \mathrm{~b}$, Jacob Adlerbeth's journal, Vol 2 , I. 818-22.

KsoGB (Kalmar Stifts- och Gymnasiebibliotek): letters from Sven Nilsson to Abraham Ahlquist. 